\title{
Mineralogical and chemical features of gangue phases in relation to hydrothermal mineralization and their host rocks
}

\author{
Javier Carrillo-Rosúa, Salvador Morales-Ruano, Purificación Fenoll Hach-Ali \\ Department of Mineralogy and Petrology, University of Granada, Avd. Fuentenueva s/n 18002 Granada, \\ Spain
}

\author{
Diego Morata Céspedes, Mauricio Belmar \\ Department of Geology, University of Chile, P. Ercilla 803, Santiago de Chile, Chile
}

Adrian J. Boyce, Anthony E. Fallick

Isotope Geosciences Unit, SUERC, Scottish Enterprise Technology Park, G75 0QF, Scotland

\begin{abstract}
Gangue minerals from hydrothermal deposits (apatite and carbonates) and their host rocks from three different volcanic areas (SE Spain, La Serena and Melipilla in Coastal Range of Chile) have been studied for broad elemental compositions. Carbonate units at the $\mathrm{Au}-\mathrm{Cu}$ Palai-Islica epithermal deposit are Fe-Mn-bearing, with a slightly higher concentration of these elements in the orebody than in adjoining hydrothermal alteration zones. Apatite has a composition that correlates with its origin and with hydrothermal processes. Thus, volcanic apatite is $\mathrm{Cl}$-rich, whereas apatite from the associated orebody is almost pure fluorapatite. Furthermore, apatite from hydrothermally altered volcanic rocks has a transitional composition between volcanic and orerelated apatite. Samples of carbonate from $\mathrm{Mn}, \mathrm{Cu}(-$ $\mathrm{Ag}$ ) and $\mathrm{Ba}-\mathrm{Ag}$ deposits in the La Serena area are all Mn-bearing calcite. In addition, $\mathrm{Mn}(\mathrm{Fe})$-poor and Mg-rich calcite is common in low-grade $\mathrm{Mn}$ areas. Similar features have been found at the Melipilla $\mathrm{Cu}(\mathrm{Cu}-\mathrm{Ag})$ deposit where epithermal calcite is also enriched in $\mathrm{Mn}(+\mathrm{Fe})$ with respect to non-mineralized veins, carbonate host rock, and metamorphic mineralization. In summary, $F$ in apatite and $\mathrm{Mn}$ have been introduced in to carbonate from the La Serena area by hydrothermal fluids and could provide an index of hydrothermal ore-forming activity.
\end{abstract}

Keywords. hydrothermal, gangue, carbonate, apatite, Spain, Chile

\section{Introduction}

Gangue minerals constitute an important proportion of hydrothermal deposits. For example, fluid inclusions and stable isotope compositions in these minerals can provide much valuable information on the genesis of ore deposits for researchers of economic geology. This contribution focuses attention on the chemical composition of apatite and carbonates from different hydrothermal deposits. This information sheds light on the genetic interpretation of the deposits studied, and provides pointers for mineral exploration.

\section{Palai-islica: epithermal Au-Cu volcanic- hosted deposit, SE Spain}

Palai-Islica is an $\mathrm{Au}-\mathrm{Cu}$ epithermal deposit hosted by calc-alkaline andesitic to dacitic rocks of the Cabo de Gata-Cartagena volcanic belt, which is a magmatic expression of the Betic Orogeny formed during extension of a thickened lithosphere (e.g. Turner et al. 1999). The deposit consists of quartz veins with sulfides, sometimes stockwork-like, and massive replacement-type mineralization in zones of intense silicification. The volcanic host-rocks are commonly hydrothermal altered, but are not considerably mineralized. Details of the ore mineralogy and geochemistry of the deposit can be found in Morales Ruano et al. (2000) and Carrillo Rosúa et al. (2002 and 2003a). This work focuses on the composition of carbonate and phosphate as an aid to discriminate between hydrothermal alteration and regional low-temperature alteration. 
Furthermore, dolomite and minor siderite are commonly formed during the later stages of mineralization. In associated hydrothermally altered volcanic rocks, dolomite very commonly replaces hornblende and plagioclase phenocrysts. Chemical analyses of both dolomites show slightly higher Fe and $\mathrm{Mn}$ in the orebody (averaging 1 at.\% Fe and 0.5 at.\% $\mathrm{Mn}$ ) than in the adjacent alteration zones (averaging 0.51 at. $\% \mathrm{Fe}$ and 0.44 at.\% $\mathrm{Mn}$ :). Idiomorphic crystals from the orebody show a chemical trend towards higher Fe and Mn content (Fig. 1). The isotopic differences between dolomite samples from the orebody $\left(\delta^{13} \mathrm{C}:-5.3--2.8 \%\right)$ and hydrothermal alteration zones $\left(\delta^{13} \mathrm{C}\right.$ : $-8.5--4.5 \%$ ) are also important. This isotopic signature suggests that the carbon in the orebody has less of a magmatic input than that in the hydrothermal alteration zones.

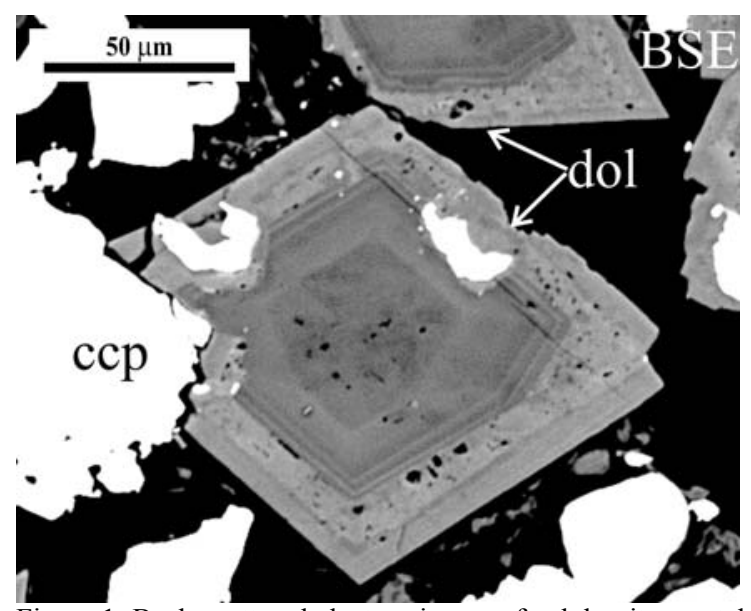

Figure 1: Back-scattered electron image of a dolomite crystal (dol) from the Palai-Islica orebody (SE Spain) with a marked zonation, the outer zones being richer (paler) in $\mathrm{Mn}-\mathrm{Fe}$ than the inner (ccp: chalcopyrite).

It is noteworthy that the volcanic rocks of Cabo de Gata have undergone a regional alteration, unrelated to the mineral deposits. Mn- and Fe-poor calcite dominates this form of alteration. The calcite commonly replaces Ca-bearing phenocrysts or forms barren veins, and is characterized by $\delta^{13} \mathrm{C}$ values of around $-12 \%$. This isotopic signature suggests that the source region had an input of organic carbon. In the areas of propylitic alteration close to the Palai-Islica deposit, calcite is replaced by dolomite (Fig. 2), marking that the influence zone of hydrothermal ore-bearing fluids overprint the regional alteration.

At the Palai-Islica deposit, apatite is a minor phase that is disseminated in quartz veins containing sulfides. In hydrothermal alteration zones, apatite is found in a mixture of chlorite \pm white mica \pm quartz \pm dolomite replacing volcanic hornblende phenocrysts. Apatite is also found in hornblende phenocrysts in andesitic to dacitic hostrocks that are not altered. The apatite in these rocks and sometimes in the orebody appears "clean" and is not porous. The apatite in the volcanic rocks may have crystallized directly from the magma, and in the orebody from hydrothermal fluids. In contrast, apatite found in hydrothermal alteration zones and sometimes in the orebody host xenotime inclusions, is always porous and is corroded. These crystals thought to be inherited from the volcanic rocks. These different styles of apatite also have distinctive compositions. Apatite in the volcanic rocks consists of $50-57 \%$ chlorapatite $24-36 \%$ hydroxylapatite, and 12-21\% fluorapatite. Apatite in the orebody is mostly fluorapatite (between 95 and $100 \%$ ) whereas apatite from the hydrothermally altered host-rock consists of 19-97\% fluorapatite, $2-50 \%$ chloroapatite, and $0-44 \%$ hydroxylapatite. These observations indicate that the composition of apatite in hydrothermally altered zones is intermediate between those in volcanic rocks and the orebody. The textural and chemical features of the apatite from Palai-Islica suggest that apatite is hydrothermal altered from high $\mathrm{Cl}, \mathrm{OH}$-rich apatites in volcanic rocks to F-rich apatites (in which evolution constituted a "trap" of REE elements for the hydrothermal fluids). Enrichment in $F$ is interpreted to relate to the intensity of hydrothermal processes and could thus provide a useful indicator of alteration and mineralization (Carrillo Rosúa and Morales Ruano, submitted).

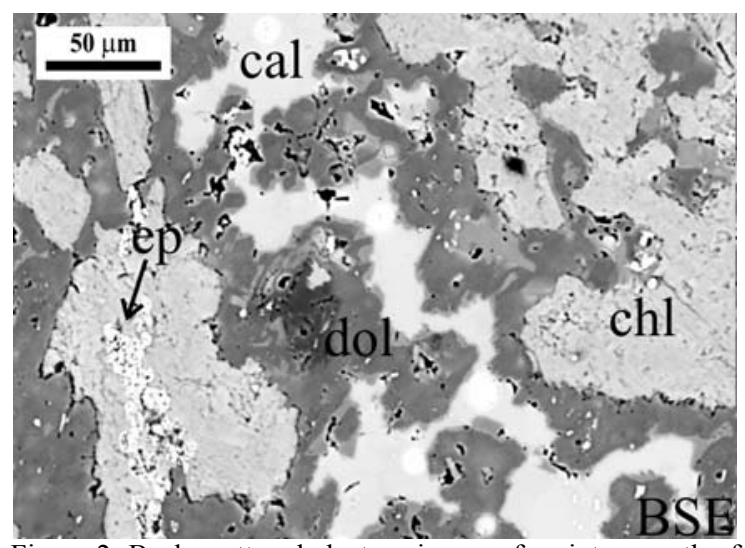

Figure 2: Back-scattered electron image of an intergrowth of dolomite crystal (dol) with chlorite (chl) and epidote (ep) in which dolomite is replacing calcite (cal) from a propylitically altered volcanic rock in the vicinity of Palai-Islica deposit. 


\section{La Serena: Mn, Cu(-Ag) stratabound, and Ba-Ag vein deposits, central Chile}

A series of $\mathrm{Mn}, \mathrm{Cu}(-\mathrm{Ag})$ stratabound and $\mathrm{Ba}-\mathrm{Ag}$ vein deposits are hosted by late Cretaceous volcanic rocks located in the La Serena region of Chile $\left(29^{\circ} 30^{\prime}\right.$ to $\left.30^{\circ} 00^{\prime} \mathrm{S}\right)$. The deposits are in thick, volcanic, plagioclase-rich, porphyritic, high-K calcalkaline to shoshonitic basaltic andesite and andesite rock, which have undergone low to very low-grade regional metamorphism (e.g. Aguirre and Egert 1965; Oyarzum et al. 1998; Morata and Aguirre 2003).

Manganese deposits in the La Serena region have ore mineralogy of braunite, piemontite, pyrolusite and hematite with calcite, barite, albite and white mica as gangue minerals (Carrillo Rosúa et al. 2003b). Calcite is the most abundant gangue mineral, which has concentrations of $\leq 0.94$ at. $\%$ $\mathrm{Mn}$ (average of 0.24 at. $\%$ ), $\leq 0.34$ at. $\% \mathrm{Mg}$ (average of 0.07 at. $\%$ ) and $\leq 0.12$ at.\% $\mathrm{Fe}$ (average of 0.02 at.\%). It is noteworthy that high-grade $\mathrm{Mn}$ areas contain calcite with low $\mathrm{Mn}$ (and Fe) content and high $\mathrm{Mg}$ content, whereas low-grade $\mathrm{Mn}$ areas are sulfide bearing and contain calcite with the opposite composition (Fig. 4).

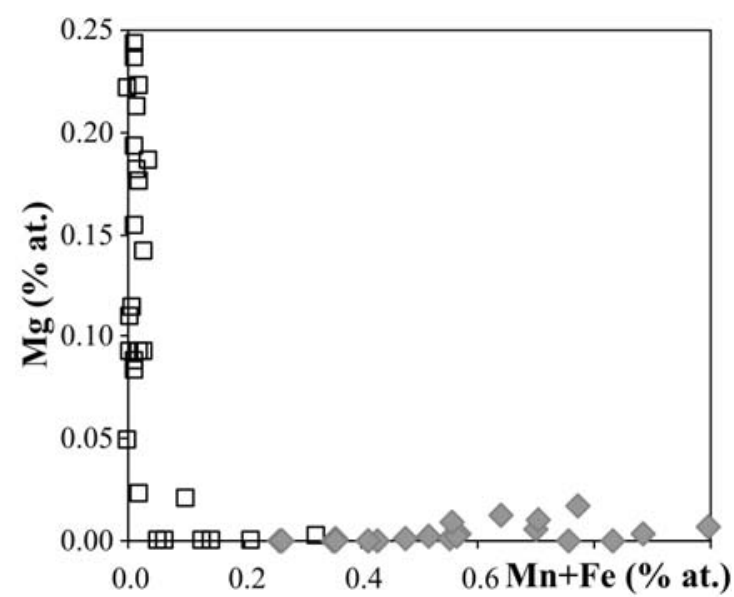

Figure 4: Binary diagram of $\mathrm{Mn}+\mathrm{Fe}$ vs. $\mathrm{Mg}$ of calcites from Mn stratabound deposit (La Serena region, Central Chile) in $\square$ Mn-rich areas non sulfide-bearing and in $>$ Mn-poor areas sulfide-bearing.

Detailed studies of the $\mathrm{Cu}(-\mathrm{Ag})$ stratabound and $\mathrm{Ba}-$ $\mathrm{Ag}$ vein deposits show that the ore contains abundant and zoned calcite (Carrillo Rosúa et al. $2003 \mathrm{~b})$. Samples of calcite from $\mathrm{Cu}(-\mathrm{Ag})$ deposits have a high Mn content (0.04-1.63 at.\%., average of 0.65 at. $\%)$, a significant Fe content $(0.00-0.45$ at. $\%$, average of 0.12 at.\%), and very low $\mathrm{Mg}$ content $\mathrm{Mg}(0.00-0.05$ at.\%, average of 0.01 at.\%), whereas calcite from Ba-Ag deposits only contains significant Mn (0.03 - 0.27 at.\%, average of 0.12 at.\%). It can be observed that $\mathrm{Mn}$ and $\mathrm{Fe}$ are proportional. Both types of deposits contain calcite with a complex zonation, suggesting that $\mathrm{Mn}( \pm \mathrm{Fe})$ calcite contain decreases towards the final stage of calcite precipitation (Fig. 5).

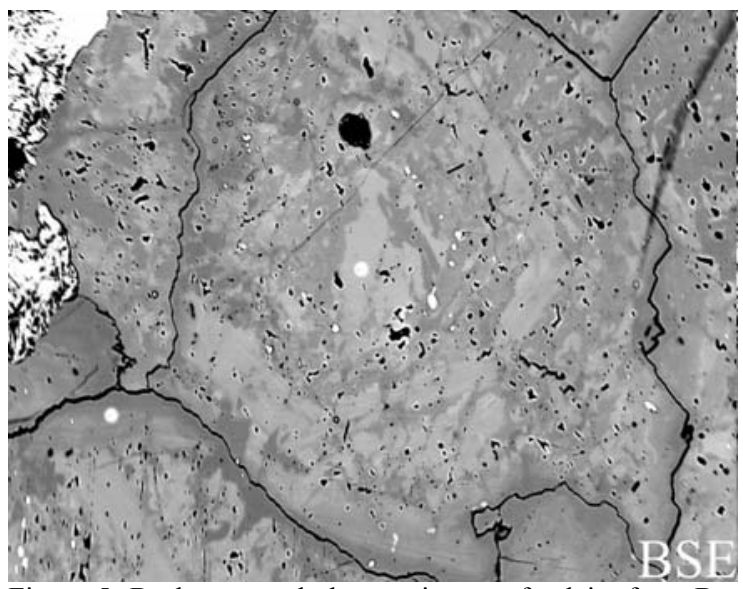

Figure 5: Back-scattered electron image of calcite from $\mathrm{Ba}$ Ag veins of the La Serena region (Central Chile) with Mnrich calcite (paler) replaced by $\mathrm{Mn}$-poor calcite.

\section{Melipilla: $\mathrm{Cu}$ (and $\mathrm{Cu}-\mathrm{Ag}$ ) hydrothermal vein and stratabound deposits, central Chile}

The $\mathrm{Cu}$ (and $\mathrm{Cu}-\mathrm{Ag}$ ) vein and stratabound mineralization of the Melipilla area in the Coastal Range of Chile $\left(33^{\circ} 45^{\prime} \mathrm{S}\right)$ is hosted by limestone and Early Cretaceous volcanic rocks similar to those in the La Serena area. Two kinds of mineralization are present in the area. The early type has a metamorphic paragenesis, and the later is epithermal containing significant quantities of calcite. The hydrothermally altered volcanic rocks also host non-mineralized or very low ore-grade calcite veins (Carrillo Rosúa et al. 2004). Calcite from the epithermal orebody usually has a high content of $0.01-1.92$ at. $\% \mathrm{Mn}$ (average of 0.44 at.\%), and a low content of $0.03-0.63$ at. $\% \mathrm{Mg}$ (average of 0.14 at. $\%$ ) and $0.00-0.16$ at. $\% \mathrm{Fe}$ (average 0.07 at.\%). This is in contrast to calcite from carbonate clasts in the host-rock to the epithermal mineralization (Mn: $0.03-0.28$ at.\%; Mg: $0.06-0.20$ at.\%; Fe: $0.01-0.11$ at.\%), from the metamorphic mineralization $(\mathrm{Mn}: 0.00-0.01$ at.\%; Mg: $0.14-0.16$ at.\%; Fe: $0.00-0.01$ at.\%) and from the non-mineralized veins in hydrothermal alteration zones (Mn: $0.04-0.07$ at.\%; Mg: 0.00 
at.\%; Fe: $0.01-0.05$ at.\%). $\mathrm{Mn}$ and $\mathrm{Fe}$ are proportional and therefore are genetically related. In addition, analysis with the highest $\mathrm{Mg}$ content, have low Fe+Mn content (Fig. 6).

\section{Conclusions}

In the hydrothermal deposits described above, gangue minerals can be used as indicators of hydrothermal activity. In the Palai-Islica deposit, F content of apatite clearly correlates with hydrothermal activity.

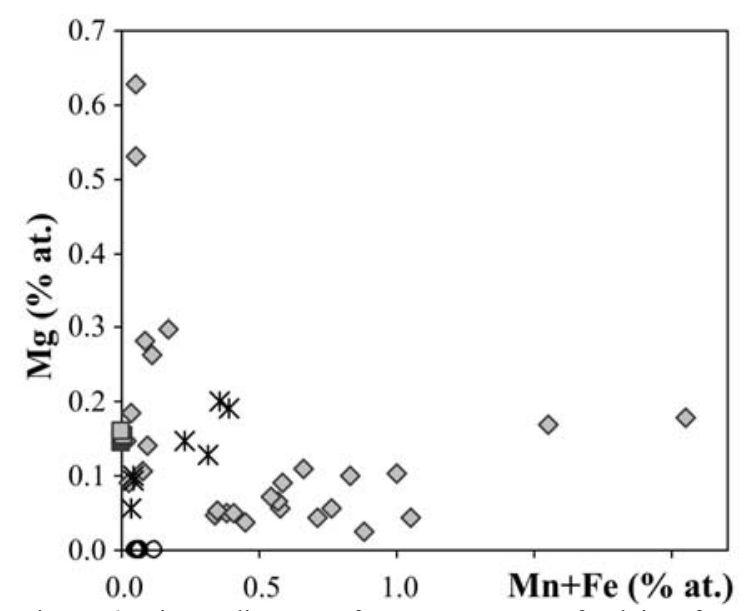

Figure 6: Binary diagram of $\mathrm{Mn}+\mathrm{Fe} v$ s. $\mathrm{Mg}$ of calcites from Melipilla area (Central Chile) in $\diamond$ epithermal $\mathrm{Cu}$ mineralization, ${ }^{*}$ carbonate clasts from the host rocks; $\square$ metamorphic $\mathrm{Cu}$ mineralization and $\odot$ non-mineralized veins in the volcanic host rock.

Carbonate veins, which are common and abundant around deposits contain significant $\mathrm{Mn}$ concentrations in the deposits studied, but are relatively poor in Mn when they are not associated with hydrothermal base-metal bearing systems. The concentration of $\mathrm{Mn}$ in calcite could thus be an element index of hydrothermal base metal-bearing fluids. Furthermore, the studies show that $\mathrm{Fe}$ usually correlates with $\mathrm{Mn}$, although it is in low concentration in calcite-bearing host-rocks and in vein-type Chilean copper deposits, and is in high concentration in dolomite from the epithermal $\mathrm{Au}-$ $\mathrm{Cu}$ volcanic-hosted Palai-Islica deposit. We also note that, in the former deposits, $\mathrm{Mg}$ and $\mathrm{Mn}$ are usually in a certain magnitude "incompatible" elements, Mg sometimes being associated with barren zones. In addition, in the Cabo de Gata area, carbonate mineralogy is a feature that can be used to distinguish between hydrothermal "hot" orebearing fluids (dolomite type) and regional "cold" non-mineralized fluids (calcite type), due to the temperature and perhaps also to the composition of the fluids (Holland et al. 1968).

\section{Acknowledgements}

The research has been supported by the project BTE-2003-06265 of the DGI, the RNM 0131 of Junta de Andalucía, the "Plan Propio" of Granada University and the I001-99/2 DID project of the University of Chile. SUERC is funded by NERC and the consortium of Scottish Universities.

\section{References}

Aguirre L, Egert E (1965) Cuadrángulo Quebrada Marquesa, provincia de Coquimbo. Carta Geológica de Chile, Instituto de Investigaciones Geológicas 15, $92 \mathrm{pp}$.

Carrillo Rosúa FJ, Morales Ruano S, Fenoll Hach Alí P (2002) The three generations of gold in the Palai-Islica epithermal deposit, SE Spain. Can Mineral 40: pp. 13931405.

Carrillo Rosúa FJ, Morales Ruano S, Boyce AJ, Fallick AE (2003a) High and intermediate sulphidation environment in the same hydrothermal deposit: the example of $\mathrm{Au}-\mathrm{Cu}$ Palai-Islica deposit, Carboneras (Almería). In: Eliopoulos DG et al. (eds), Mineral exploration and sustainable development. Millpress, pp. 445-448.

Carrillo Rosúa FJ, Morales Ruano S, Morata Céspedes D (2003b) Mineral features of Cu-Ag-Ba-Mn mineralisations of La Serena, Chile. In: Eliopoulos DG et al. (eds), Mineral exploration and sustainable development. Millpress, Rotterdam, pp. 953-956.

Carrillo Rosúa FJ, Morales Ruano S, Morata D, Belmar M, Fenoll Hach-Alí P (2004) Mineralogía de los depósitos de cobre de la Melipilla (Cordillera de la Costa, Chile Central). Datos preliminares. Macla 2: pp. 91-92.

Carrillo Rosúa FJ, Morales Ruano S (submitted). Major elements composition of apatite in the $\mathrm{Au}-\mathrm{Cu}$ epithermal deposit of Palai-Islica (Almería, SE Spain) as an indicator of hydrothermal alteration. European J of Mineral.

Holland HD (1968) Gangue minerals in hydrothermal deposits. In: Barnes HL (ed), Geochemistry of hydrothermal Ore deposits John Wiley \& Sons, New York, 2nd edn, pp. 382-436.

Morales Ruano S, Carrillo Rosúa FJ, Fenoll Hach-Alí P, de la Fuente Chacón F, Contreras López E (2000) Epithermal $\mathrm{Cu}-\mathrm{Au}$ mineralization in the Palai-Islica deposit, Almería, Southeastern Spain, fluid inclusion evidence of mixing of fluids as guide to gold mineralization. Can Mineral 38: pp. 553-566.

Morata D, Aguirre L (2003) Extensional Lower Cretaceous volcanism in the Costal Range $\left(29^{\circ} 20^{\prime}-30^{\circ} 00^{\prime}\right.$ S) Chile: geochemistry and petrogenesis. J of South American Earth Sciences 16: pp. 459-476.

Oyarzun R, Ortega L, Sierra J, Lunar R, Oyarzun J (1998) $\mathrm{Cu}, \mathrm{Mn}$ and $\mathrm{Ag}$ mineralization in the Quebrada Marquesa Quadrangle: the Talcuna and Arqueros district. Miner Deposita 33: pp. 547-559. 